\title{
Carlos Casares, autor dramático. Unha revisión crítica
}

\section{Carlos Casares, a Playwright. A Critical Review}

\author{
MANuel F. Vieites \\ (Universidade de Vigo) \\ mvieites@uvigo.es \\ Recibido: enero de 2017. Aceptado: marzo de 2017
}

\begin{abstract}
Resumo: Carlos Casares é autor dun único texto dramático publicado, no que propón un novo modelo de creación dramática nun momento en que o campo literario galego estaba plenamente mediatizado pola loita contra a ditadura, polas liberdades e polo recoñecemento do carácter diferencial da nación galega. Neste artigo propoñemos unha lectura do texto nese contexto sociocultural e político, pero tamén á luz de diferentes teorías que permite considerar ata que punto no texto de Casares se estaban asentando os principios básicos do que se ten definido como literatura nacional, unha praxe artística que supera a instrumentalización e promove a autonomía discursiva.
\end{abstract}

Palabras clave: Complexidade, estrañamento, caos, azar, pensamento diverxente, realismo máxico.

\begin{abstract}
Carlos Casares is the author of a single published dramatic text, where he proposes a new model of dramatic enactment at a time when the literary field was fully mediated by the struggle against dictatorship, for freedom and for the recognition of the differential character of the Galician nation. In this paper we propose a reading of the text in that sociocultural and political context, but also to the light of different theories which allow us to consider to what extent this text by Casares was settling the basic principles of what has been defined as national literature, an artistic praxis with a strong discursive autonomy and devoid of instrumentalism.
\end{abstract}

Key Words: Complexity, defamiliarization, chaos, chance, divergent thinking, magic realism. 


\section{INTRODUCIÓN}

En 1973 As laranxas máis laranxas de tódalas laranxas, obra dramática da que era autor Carlos Casares, obtiña o primeiro premio no Concurso de Teatro Infantil Galego convocado por primeira vez naquel ano pola Agrupación Cultural O Facho ${ }^{1}$ para celebrar o seu décimo aniversario. O espectáculo homónimo, con dirección de Xosé Manuel Rabón, sería estreado polo Grupo Teatral O Facho, da dita agrupación, no peche da Primeira Mostra de Teatro Galego, que naquel mesmo ano iniciaba andaina en Ribadavia. O texto volvería a Ribadavia en 1980, nun espectáculo homónimo do grupo Ítaca, de Vilagarcía, con dirección de Eduardo Puceiro, e máis recentemente foi obxecto de cando menos dúas escenificacións profesionais, realizadas e producidas polo Centro Dramático Galego, con dirección de Jose Caldas, en 2004 e 2014, sendo a segunda unha reposición da primeira. Dúas versións dun espectáculo que malia a notable pericia no equipo de actores e actrices, non souberon afondar, na nosa opinión, en todo aquilo que a peza traslada en toda a súa textura literaria e mesmo científica, en todo aquilo que nos quere dicir sobre a natureza da realidade (Vieites, 2004, 2005, 2014), como tamén se dirá e xustificará máis adiante.

Sendo a investigación específica sobre a literatura para a infancia e a mocidade un ámbito relativamente novo en Galicia ${ }^{2}$, como tamén o é no relativo ás prácticas teatrais que ten xenerado esa creación dramática específica (Ogando González, 2007), non son moitos os traballos que se ocupen do texto en cuestión. Un volume recente, coordinado pola profesora Roig Rechou (2015), ofrece unha guía moi completa sobre o territorio da literatura infantil e xuvenil, no que atopamos traballos panorámicos sobre a creación dramática asinados por Roig Rechou, Fernández Vázquez e Ferreira Boo, Agrelo Costas ou Neira Rodríguez, que complementan e amplían outros anteriores tamén centrados na literatura dramática (Roig Rechou, 2004; Roig Rechou + López, 2007). Sobre a figura de Carlos Casares como autor de literatura infantil existe xa unha bibliografía pertinente, na que se destaca o seu papel fundamental no desenvolvemento do xénero (Roig Rechou, 2002; Alonso, 2003; Fernández Vázquez, 2012; Pena Presas, 2014); en relación ao texto As laranxas máis laranxas de tódalas laranxas bastantes traballos ofrecen unha perspectiva xeral do mesmo, indicando a súa relevancia e novidade, especialmente pola altura na que se publica, mais non existen estudos que aborden eses trazos de relevancia e novidade, cunha certa fondura, e seguen sendo referencia obrigada os debidos a Roig Rechou (2004, 2007) ou Fernández Vázquez (2011).

Na nosa opinión a transcendencia do texto reborda con moito o campo da literatura dramática para a infancia e a mocidade, en tanto aparece nun momen-

${ }^{1}$ En relación ao asociacionismo galego dos anos sesenta e primeiros setenta son relevantes os traballos de Lourenzo, Santamarina, Harguindey Banet ou Caamaño Suárez contidos no volume Un canto e unha luz na noite. Asociacionismo cultural en Galicia (1961-1975), coordinado por Gurriarán (2012).

2 Outro tanto podemos afirmar en relación ao ámbito de expresión castelá ou catalán, considerando que o primeiro traballo de entidade sobre a literatura dramática e o teatro de/para a infancia e a mocidade é o que publica Juan Cervera en 1982. 
to en que se estaban a poñer os cimentos do que podería ou debería ser a literatura dramática e o teatro de expresión galega, e no que calquera texto que aparecía na esfera pública era obxecto de escrutinio crítico en función do modelo proposto. Se como sinalaba o profesor González Millán «o gran desafío dos primeiros anos do posfranquismo foi precisamente a configuración dun discurso literario capaz de conciliar as esixencias do mencionado proceso de autonomía [do campo literario] e a súa instrumentalización como fórmula na articulación da identidade nacional» (1998: 30), un dos desafíos dos últimos anos do franquismo era promover a autonomía do discurso literario fronte a unha instrumentalización que as máis das veces resultaba tan banal como estéril.

O ámbito da literatura dramática en lingua galega (os textos) e o da creación teatral (os espectáculos) sentiu con forza esa aposta pola razón instrumental ${ }^{3}$, como veremos máis adiante, e como mostra sirva a negativa de Manuel María a que o texto con que gaña ex-aequo o primeiro premio do Concurso Abrente de obras teatrais, $O$ meu mundo non é deste reino, se publique na colección Arealonga, da editorial Akal, ao non ser unha editorial galega (López Silva + Vilavedra, 2002: 149). En relación a esa dimensión instrumental tan instalada na creación cultural do país (que por outra parte tamén estaba presente na creación de expresión castelá ou catalá) Lourenzo e Pillado, na súa análise das Mostras de Ribadavia, sinalan:

Ao longo das cinco primeiras mostras, dominaron criterios políticos elementais, tanto na concepción dos espectáculos como no groso dos debates. Raramente se ten estudado un traballo cunha base ideolóxica e metodolóxica axeitada ao seu discurso. A simplificación era a arma preferida do dogmatismo. Correntes e opinións políticas teñen suplantado arreo os argumentos ideolóxicos e estéticos. A atmósfera, por decilo dunha maneira gráfica, estaba viciada (1979: 153).

Con Zardigot de Rodríguez Ruibal, a outra peza premiada ex-aequo naquel Primeiro Concurso, pero con outros textos que se dirán, As laranxas... supón unha tentativa de defender a autonomía da creación artística diante da súa instrumentalización (Fernández Paz, 1989; Alonso, 2003), pero tamén a posibilidade de que os discursos críticos se constrúan desde a propia literariedade, ou por utilizar palabras de Hjelmslev, desde a forma mesma da expresión e do contido (1972).

Con este traballo queremos afondar no estudo da singularidade recoñecida dun texto que, como acontecera con Alén (1921) de Xaime Quintanilla (Vieites, 2003), pode ser considerado, seguindo a proposta de González Millán (1994),

3 Ao falarmos de «razón instrumental» seguimos a visión que da mesma nos ofrecen autores como Max Horkheimer (2000) ou Jürgen Habermas (1982), na súa denuncia do pensamento binario, dicotómico, asentado en antinomías, tan propio dos movementos (neo)conservadores, que o son con independencia da ideoloxía que para si demanden. Fronte á razón instrumental, os dous filósofos da Escola de Frankfurt propoñen unha razón crítica, fundamento do que se coñece como «teoría crítica», que procura unha análise dialéctica da realidade social na perspectiva da complexidade, e que en boa medida tamén está moi presente na peza de Carlos Casares que comentamos. 
entre as primeiras tentativas, pero en ningún caso únicas, de crear en Galicia unha literatura nacional nun campo cultural plenamente autónomo, merecemento que partilla con outros textos moi notables, desde $O$ desengano do prioiro (1952) de Ramón Otero Pedrayo até Vinte mil pesos crime (1962) de Bernardino Graña. Unha autonomía discursiva moi difícil de defender naquela altura fronte ás propostas de instrumentalización procedentes do ámbito cultural e político, por canto «o obxectivo último de todo nacionalismo literario é consolidar e lexitimar un determinado ideario nacional(ista)» (González Millán, 1994: 78), no que cobran especial relevo os relatos e as metáforas da nación oprimida, que non empecen a dimensión artística dos produtos culturais xerados pero que si lles confiren unha deteminada formalización simbólica, semántica e pragmática.

\section{CARLOS CASARES NA DRAMÁTICA GALEGA}

Cando a editorial Galaxia publica As laranxas..., Carlos Casares tiña publicado obras como Vento ferido (1967) A galiña azul (1968) ou Cambio en tres $(1969)^{4}$. Vai ser o seu primeiro e único texto dramático nunha carreira literaria máis orientada á narrativa aínda que haxa tamén que destacar o seu traballo como columnista na prensa escrita. Naquela altura, 1973, bota a andar a Mostra de Teatro de Ribadavia, e o Concurso de Obras Teatrais en Galego Abrente, que na primeira convocatoria, nese mesmo ano, reciben ex aequo Euloxio R. Ruibal por Zardigot (1974) e Manuel María por O meu mundo non é deste reino ${ }^{5}$. Estamos pois, como se ten salientado (López Silva + Vilavedra, 2002), no momento en que se inicia o proceso de reconfiguración dos campos e dos sistemas que lles son propios á literatura dramática e ao teatro.

Certamente antes de 1973 a escrita dramática e a creación teatral daban mostras evidentes de recuperación, mais tratábase de fenómenos que tomados no seu conxunto e mesmo considerando algunhas excepcións (Vieites, 1998; Riobó, 1999) carecían de verdadeiro alcance cuantitativo, polo que non se podían cualificar como substantivos, mesmo atendendo, no caso da escrita dramática, a espazos para a difusión, a recepción crítica e a investigación. As voces da nosa dramática, sendo moi notables, eran moi poucas, e na maioría dos casos tampouco non eran moi prolíficas. Entre as pezas publicadas hainas de Xosé Luís Franco Grande (Vieiro choído, 1957), Álvaro Cunqueiro (O incerto señor Don Hamlet, 1958), Arcadio López Casanova (Orestes, 1963), Jenaro Marinhas del Valle (A revolta, 1965), Xohana Torres (Á outra banda do Iberr, 1965),

${ }^{4}$ Sobre a primeira obra citada, Piñeiro Pais (2015) ten publicado un interesante traballo onde establece interesantes vínculos entre a obra narrativa de Dieste e a de Casares, alén de destacar a vontade realista deste autor na definición do cronotopo dos seus relatos, algo que tamén acontece en As laranxas..., malia que nesta peza teñamos que falar dun realismo que se torna máxico desde o inicio mesmo da acción.

5 O texto sería convertido en espectáculo polo grupo Tagallo, de Perlío, co nome de Farsa de Bululú, título co que se publicaría en 1992 nunha edición non venal patrocinada por El Correo Gallego. En 2006 sería editada por Xerais, co mesmo título. 
Daniel Cortezón (Prisciliano, 1970), Manuel María (Auto do mariñeiro, 1970), Ricardo Carballo Calero (Catro pezas, 1971), Tomás Barros (O dragón, 1972), ou Eduardo Blanco Amor (Farsas para títeres, 1973), por falarmos dos máis coñecidos. Se ben os textos escritos eran máis, non estaban aínda presentes na esfera pública, tampouco a través da creación escénica, que comeza a coller pulo a primeiros dos setenta. Considerando aos que por idade poderían ser compañeiros de xeración (e mesmo admitindo que o criterio xeracional poida ser discutible), e tendo en conta que nace en 1941, podemos dicir que Casares publica no campo dramático despois de Arcadio López Casanova (1942), pero antes de Manuel Lourenzo (1943), Xosé Manuel Rodríguez Pampín (1940), Euloxio Rodríguez Ruibal (1945), Francisco Taxes (1940), ou Xosé Agrelo Ermo (1937).

No eido da creación teatral, contra 1973 había varios núcleos de traballo activos, quer no teatro comunitario ou escolar quer no teatro independente, pero só comezan a utilizar a lingua galega, e de maneira progresiva, a partir de finais dos sesenta ou nos primeiros setenta ${ }^{6}$. Casos paradigmáticos poden ser os de Ditea, que en 1970 presenta A comedia da oliña, con dirección de Agustín Magán; a Agrupación Teatral Valle-Inclán de Ourense, que nese mesmo ano escenifica Don Hamlet, con dirección de Segundo Alvarado; o grupo Rosalía de Castro, de Santiago, que en 1970 debuta con A arbre, dirixido por Rodolfo López-Veiga; o grupo da Extensión Agraria de Reinante, que en 1971 presenta Os vellos non deben de namorarse, con dirección de Eduardo Gutiérrez, ou Tespis, que en 1973 ofrece A noite vai coma un río, con dirección de Xosé Redondo. Pioneiros no uso do galego naquela altura, para alén dalgunhas propostas do teatro universitario, foron o grupo de teatro da Asociación Cultural O Facho, creado por Manuel Lourenzo en 1965 e que naqueles anos realiza un espectáculo por ano; a Aula de Teatro do Liceo de Betanzos, creada por Antón Concheiro Caamaño en 1968, cando presenta $O$ que dixo si, o que dixo non, con Brecht como pretexto; Teatro Circo, grupo creado por Manuel Lourenzo, que en 1968 estrea o espectáculo Longa noite de pedra, a partir de poemas de Celso Emilio Ferreiro; o Teatro Popular Galego, cos espectáculos A raposa e as uvas (1966) e A puta respetuosa (1968), con dirección de Maximino Keyzán, ou o Teatro de Cámara As Burgas que en 1969 escenifica Os vellos..., de Castelao (Lourenzo Modia, 2012).

A literatura dramática para a infancia e a mocidade, naquela altura de 1973, apenas tiña referentes propios, para alén dalgunhas pezas publicadas antes de 1936, ou Barriga verde de Manuel María ${ }^{7}$, editada en 1968 por Castrelos en

${ }^{6}$ Está por escribir a historia do teatro nas cidades e vilas de Galicia, especialmente na perspectiva do que se coñece como «microhistoria» (Aróstegui, 1995: 142). Nesta dirección ten especial interese a lembranza de Manuel Lourenzo (2012) sobre os seus anos mozos, ou a historia do Teatro Circo contada por Lourenzo Modia (2012), que serven para reconstruír o acontecer teatral nunha cidade como A Coruña nos anos sesenta e setenta.

7 Sobre o personaxe de Barriga Verde, paga a pena consultar a tese de Comba Campoy (2015) na que comenta o periplo artístico do seu creador, José Silvent Martínez. Sobre o texto de Manuel María existen varios traballos, entre eles o de Calvo (2012). Para a obra dramática de Manuel María, García Negro (2009). 
Vigo. Certamente en 1973 aparecen Tres cadros de teatro galego, de Dora Vázquez, ou a versión galega que Daniel Cortezón fai da peza de Jorge Díaz, Os anxos cómense crús; en 1974 sae do prelo Teatro pra a xente, de Eduardo Blanco Amor, que incluía Fas e Nefas ou o castelo enmeigado número 5.000 e pico, ou Monicreques, das irmás Dora e Pura Vázquez. Os Concursos O Facho serán fundamentais para promover este ámbito creativo específico, na literatura e no teatro, que por volta de 1973 estaba aínda en proceso de configuración, e procurando modelos nun momento en que unha boa parte da creación cultural galega vivía abeirada aos movementos e loitas polas liberdades colectivas e comunitarias, nunha complexa batalla política na que interviñan forzas diversas, en ocasión fortemente enfrontadas entre si. Unha mostra desa dinámica de confronto en relación coas orientacións da praxe escénica pode estudarse no desenvolvemento das Jornadas de Teatro de Vigo, que aspiraban a ser un festival ibérico de teatro, antes de que en Porto comezase por volta de 1978 o Festival Internacional de Teatro de Expresión Ibérica (López Silva + Vilavedra, 2002: 201-211), malia que as interpretacións verbo do dito festival e das súas implicacións sexan diverxentes (Vieites, 1998; López Silva + Vilavedra, 2002; Lorenzo Modia, 2012).

Volvendo a 1973, son varios os acontecementos que cabe considerar para establecer o contexto no que irrompe a peza de Carlos Casares e para valorar na xusta medida a súa singularidade. Ao noso entender, nas dúas primeiras edicións da Mostra de Teatro de Ribadavia, as de 1973 e 1974, participan un monllo moi heteroxéneo de grupos, desde os procedentes de agrupacións culturais ou centros educativos, ata os que se situaban no teatro afeccionado ou no teatro independente ${ }^{8}$. Nesas dúas primeiras edicións mestúranse algunhas tendencias fundamentais: (a) as propostas escénicas con carácter instrumental propias dun teatro cunha orientación social e política, moitas veces abeiradas a un galeguismo moi diverso na súa praxe; (b) aquelas que propoñen recuperar autores canónicos na tradición dramática galega, como Rafael Dieste, Jenaro Marinhas del Valle, Álvaro de las Casas, Eduardo Blanco Amor ou Ricardo Carballo Calero, e (c) algunhas novidades escénicas máis intuídas que realizadas que se incorporaban desde as experiencias do teatro independente e as súas formas de facer.

Pola súa vez, as diferentes maneiras de entender a creación dramática vanse manifestar con forza con ocasión do segundo Concurso de Obras Teatrais en Galego Abrente, especialmente nas deliberacións e posicións dun xurado integrado por Eduardo Blanco Amor, Xavier Fábregas, Manuel María, Euloxio Rodríguez Ruibal e Francisco Rodríguez, cando resultan gañadoras A tola xuiciosa de Manuel Domínguez Quiroga e A volta de Edipo, de Ánxeles Penas 9 . A

${ }^{8}$ Como explicamos noutro lugar (Vieites, 2001), cabe establecer diferenzas entre as agrupacións afeccionadas e os grupos que se vinculan co movemento do teatro independente, que se manifestou xa nos anos cincuenta e primeiros sesenta como un fenómeno internacional antes de ser ibérico (De Marinis, 1987). Sendo non profesionais por dedicación, na súa orientación artística, nos seus procesos de traballo e na formalización escénica dos seus espectáculos, os grupos que a si mesmos se denominaban ou consideraban independentes mantiñan notables diferenzas cos grupos amadores, pero tamén so seu devezo evidente de profesionalidade (Vieites, 2009).

9 Resulta moi esclarecedora a nota que escribe Doro Piñeiro para lembrar a súa participación en Ribadavia en 1974, onde presenta o espectáculo Estebiño, cun texto de Xavier Prado Lameiro, 
polémica xorde cando Blanco Amor, diante dos debates que comezaban a agromar en Galicia, e particularmente en Ribadavia, arredor das orientacións temáticas e formais da escrita e da creación teatral, explica que «o teatro non se fai pra os grupos, os grupos fanse pra o teatro» (López Silva + Vilavedra, 2002: 118-119). En realidade era a mesma posición que adopta no prólogo ao volume Teatro pra a xente, en defensa do que denominaba «o púbrico do común», e en defensa da súa propia poética, asentada na necesidade de ofrecer lecer e divertimento a unha xente que «forma a máis grande maioría do noso pobo» $(1974: 7,9)$, lonxe daquela lingua «en que tan requintadamente falamos i escribimos uns intelectuais pra os outros ou pra uns leitores minoritarios» (1974: 9). Velaí o sentir do xurado, que, coa excepción de Euloxio Ruibal, reflectía nas actas ter adoptado como criterio na concesión do premio «tanto como os méritos literarios intrínsecos das obras, a posibilidade de que se axusten ás circunstancias culturais e sociais que nos requiren un teatro coa suma maior de posibilidades de ser representado diante de auditorios preferentemente populares» (López Silva + Vilavedra, 2002: 150).

A polémica sempre latente arredor da orientación estética, semántica ou pragmática da creación cultural e teatral, abrollaba nos discursos que se facían públicos en marcos de debate e reflexión. Nun traballo publicado en 1970 na revista Primer Acto, Manuel María, poeta e dramaturgo, e notable activista cultural de filiación nacionalista, explicaba como «en el teatro gallego no hay obras vanguardistas - de una vanguardia que ya va dejando de serlo- o de teatro del absurdo, que tampoco es ya ninguna novedad» (1970: 17). E na súa defensa dun teatro instrumental, de axitación e propaganda, destacaba:

La juventud, afortunadamente, tiene una nueva concepción del teatro. En su ánimo está que el teatro no sea solamente, como lo vino siendo hasta el presente, un espectáculo para burgueses, sino algo auténticamente vivo, un mensaje que llegue al pueblo de verdad. Los primeros pasos dados en este sentido parece que van por buen camino e inteligentemente orientados. Entre nosotros están cambiando muchas cosas. Y confiamos en que el teatro gallego será, en breve, una realidad como ya lo es, por ejemplo, la «Nova Canción Gallega» (1970: 17).

Nesa referencia á Nova Canción Galega, a Voces Ceibes en definitiva, atopamos unha definición explícita do que un sector da intelectualidade reclamaba: a creación dun teatro de liberación nacional, ou por dicilo con palabras de Manuel Guede «un teatro nacional, científico, popular e democrático» (2002: 243).

co grupo Escoitade de Valladares, Vigo (López Silva + Vilavedra, 2002: 269-273). A recepción do espectáculo por parte dos «universitarios progres», fronte á do resto do auditorio, dá conta da existencia xa daquelas dunha sorte de fenda entre o que con Bourdieu (1995) se podía considerar «gran produción»e «produción restrinxida», conceptos que na súa cerna sociolóxica e polas dinámicas que refiren son aplicables a calquera sistema de producción simbólica, cultural e artística, con independencia do seu nivel de desenvolvemento, pois dan conta dos xogos de poder entre os axentes do campo e os seus produtos, e mesmo entre as institucións emerxentes do mesmo (como a crítica). 
No meso número, Manuel Lorenzo, formulaba a necesidade de «crear equipos de trabajo, estudios, en cualesquiera condiciones, a fin de proponer unas formas, una estética, que tengan su raíz en las necesidades populares de un país eminentemente pobre y aldeano» (1970: 27). Sen embargo, Euloxio R. Ruibal, nun artigo titulado «¿Unha nova xeira do noso teatro?» defendía que «sen un exhaustivo conocemento do teatro avangardista doutras latitudes dificilmente se poderá camiñar i esperimentar cara un teatro propiamente galego de calidade estética, un teatro que comunique e exprese éticamente a nosa problemática?» (1974). Velaí algúns aspectos dun debate que non cabe entender en termos de tradición e vangarda, pois tanto un concepto coma o outro eran entendidos de forma diversa, e así había quen defendía a vella tradición do teatro rexionalista e quen apostaba pola recuperación de formas escénicas tradicionais que grupos como o Odin Teatret, con Eugenio Barba, estaban a converter nunha das liñas da experimentación máis vangardista (Innes, 1992).

Un debate tenso e intenso, no que participaron múltiples voces (Lourenzo Modia, 2012) e que mostraba diferentes formas de proceder nun campo literario e nun sistema teatral en proceso de configuración, moi abeiradas esas voces ao concepto de «nacionalismo literario» (González Millán, 1994). Como temos escrito noutro lugar, no xurado e nos participantes activos na polémica reflectíanse tres tendencias fundamentais: (a) a dos que «entendían que la dramática debería tener un carácter fundamentalmente realista y social», (b) a dos que «apostaban por una estética aún más 'popular' basada en la adecuación de las propuestas a lo que se tomaba como modelo de lector o espectador real», e (c) un terceiro grupo que «defendía la creación dramática como ámbito de experimentación e investigación abierto a las más diversas corrientes y tendencias» (Vieites, 1996: 14). Nesa mesma dirección, López Silva e Vilavedra, na súa historia da Mostra Abrente, sinalan como a maioría dos axentes implicados nas primeiras edicións da mesma tiñan unha clara «consciencia da necesidade dun teatro que servise os intereses ideolóxicos e socio-culturais de Galicia» (2002: 47).

Neste contexto de debate arredor das orientacións estilísticas, simbólicas ou pragmáticas da creación cultural en lingua galega, nomeadamente a escrita dramática, é onde se sitúa a peza de Carlos Casares; unha peza que, segundo a nosa opinión, debedora da de Fernández Paz (1989) ou da de Fran Alonso (2003), se relaciona con aquela vontade de autonomía da creación literaria da que tanto ten escrito onda nós González Millán. Nos seus traballos arredor da lexitimación das prácticas culturais en procesos de loita pola hexemonía, este último autor lembraba o peso que en Galicia vai ter a identidade colectiva e unha «determinada concepción da identidade galeguista» (González Millán, 1998: 17), que todo texto tiña necesariamente que potenciar. Nesa dirección vaise conformando un canon de resistencia e emancipación, que inclúe ou exclúe textos, pois como tamén sinalaba González Millán «a relevancia das obras literarias máis destacadas ía sempre da man da súa condición de textos alegóricos e fundacionais: a súa hipotética literariedade dependía dunha determinada afiliación nacional que os textos en cuestión axudaban a articular» (1998: 17). E na nosa modesta opinión o texto de Carlos Casares quere camiñar nunha dirección diferente, optando por unha consideración da literaridade allea a esas alegorías fundacionais ou ás antinomías vellas e novas que os textos conformaban como 
as de amo / servo ou estado opresor / terra asoballada, e que naquela altura en ningún caso deixaban de ter sentido.

Por iso entendemos que en As laranxas... se propón un paradigma diferente aos que naquela altura loitaban por ser dominantes como antes se sinalou en relación á polémica do premio literario Abrente (López Silva + Vilavedra, 2002), ou como nos lembra Fernández Paz na súa lectura da peza (1989), e a súa transcendencia afecta á consideración mesma da literatura galega como campo de creación no seu conxunto, e non se limita ao ámbito da creación literaria para os máis novos. Unha aposta por unha literatura non instrumental e verdadeiramente nacional.

\section{DA COMPLEXIDADE AO CAOS}

Vai para uns anos que Alan Sokal e Jean Bricmont alertaran verbo do uso indiscriminado e pouco ortodoxo de termos científicos en áreas de coñecemento alleas aos propios termos, desde os estudos culturais aos literarios, sinalando como malia a reputación de certos textos de seren difíciles, o feito de que semellen incomprensibles obedece a que «no quieren decir nada» (1999: 23). Como comentaba Mario Bunge en torno aos excesos textualistas da posmodernidade, os seus profetas, sumos sacerdotes e acólitos «se limitan a hacer afirmaciones, mientras más herméticas y menos fundamentadas mejor» (2002: 30).

E sen embargo, non é menos certo que a visión que da realidade aportan as ciencias puras, mesmo a filosofía, pode ser especialmente estimulante para o estudio doutras realidades, como a artística, e dentro dela a literaria. Conceptos como azar, caos, complexidade, lóxica difusa, fractalidade, cabo doutros máis vellos como «stasis», xunto coas teorías que sobre a realidade contribúen a formular, son ben estimulantes para describir, explicar e interpretar a textualidade literaria, pois certamente a literatura non é allea aos desenvolvementos da filosofía, da ciencia ou da tecnoloxía.

A bibliografía divulgativa existente en relación a temas como a complexidade (Morin, 1994), o caos (Gleick, 1988), a lóxica difusa ou borrosa (Kosko, 1995) ou a «stasis» (Hoppmann, 2014), é abundante; tamén o é no relativo á súa aplicabilidade no eido dos estudos literarios, como manifestan os traballos de Brady (1990), Hayles (1990), Reed (1996), Kundert-Gibbs (1999), Hippolyte (2006), MaCarthy (2006), aínda que non falten traballos que a cuestionen (Matheson + Kirchhoff, 1997). Cunha posición máis matizada, Kellert analizando diferentes achegas que vinculan creación literaria e teorías do caos sinala que «some of these attempts to make use of chaos theory merit serious attention, some are harmless speculation, and some are simply misleading» (2008: 2).

Non obstante as críticas, non deixa de ser certo que Julio Cortázar en novelas como Rayuela (na súa estrutura), ou en relatos «Carta a una señorita en París» (no incidente inicial e na cadea posterior de acontecementos que provoca), crean unha realidade na que encontramos aqueles trazos que tradicionalmente se vinculan coas teorías sinaladas (Valenzuela, 2002: 16). Outro tanto 
acontece na peza Un chapeu de palla italiana ${ }^{10}$, de Eugène Labiche, na que un suceso inicial, que o cabalo de Fadinard coma o sombreiro dunha moza, provoca unha serie de acontecementos que ameazan, pola súa complexidade e o caos conseguinte, a resolución de problemas diversos, entre eles o casamento do mozo ou preservar o bo nome dunha moza.

A complexidade, en palabras de Morin, supón «una cantidad extrema de interacciones e interferencias entre un número muy grande de unidades» (1994: 59), polo que «siempre está relacionada con el azar» (1994: 60), e «coincide con un aspecto de incertidumbre, ya sea en los límites de nuestro entendimiento, ya sea inscrita en los fenómenos» (1994: 60). Fronte ao paradigma da simplicidade, «que pone orden en el universo» (1994: 89), a complexidade vai ao encontro do azar, en tanto o azar forma parte da realidade, á que configura, pois «el mundo se organiza desintegrándose» (1994: 93). A conciencia e a vivencia da complexidade, en definitiva, «nos vuelve prudentes, atentos, no nos deja dormirnos en la mecánica aparente y la trivialidad aparente de los determinismos» (1994: 117). Fainos libres en tanto aumenta a nosa autonomía cognitiva e a nosa comprensión do mundo (Morin, 2016).

As laranxas... mostra un mundo en aparencia simple, con elementos propios da realidade cotiá. Sen embargo, xa nas primeiras frases coas que o dramaturgo implícito ${ }^{11}$ recrea esa realidade, aparecen elementos extracotiás, inesperados, que provocan indeterminación e incerteza, e que aumentan coa referencia a «cinco laranxas enormes. As laranxas máis grandes do mundo» (Casares, 1993: 8) $)^{12}$. Nese mundo, tal e como se nos mostra, hai, de partida, un conflito latente, de carácter cognitivo, pois cómpre darlle sentido ao que a realidade contén e que cae fóra da lóxica discreta. Como sinala Velarde Lombraña, en relación á visión que propón a lóxica difusa:

(...) en la medida en que crece la complejidad de un sistema, en esa misma medida disminuye nuestra capacidad para hacer precisos y aun significativos enunciados acerca de su conducta, hasta alcanzar un umbral, más allá del cual la precisión y la significación (o relevancia) resultan, casi siempre, características mutuamente excluyentes (1996: 436).

${ }^{10}$ Existe versión galega, realizada por Ana Luna e publicada pola Universidade de A Coruña en 2004.

${ }^{11}$ En diversos traballos temos proposto que o dramaturgo implícito sería aquela voz que desde o mundo dramático configurado organiza e formaliza e presenta a súa enunciación dramática, en especial o texto secundario, no que establece tempos, espazos ou accións, pero tamén dando voz aos personaxes (Vieites, 2008, 2016). Unha hipótese de traballo en curso e en proceso de falsación.

12 Nesa dirección cabería considerar que a obra mantén relacións evidentes co realismo máxico, tanto porque non se axusta aos parámetros da literatura fantástica ao estar ancorada no real, como por introducir «fenómenos de lo sobrenatural y lo insólito dentro del quehacer cotidiano de sus personajes», que sería un dos trazos desa corrente literaria (García Valero, 2012: 1), que ten en Álvaro Cunqueiro un dos seus precursores (López Guil, 2005), e coñecida é a relación entre o mindoniense e o de Xinzo (Basanta, 2012), como se pode comprobar en textos como $O$ galo de Antioquía (1994). 
Ademais o mundo que recrea As laranxas... aumenta a súa complexidade, a súa «borrosidade», a medida que vai sendo formulado polo dramaturgo implícito, coa irrupción de Elías e a súa atípica caracterización, a de Anxa e a dos veciños e veciñas, que, cada quen coa súa propia extravagancia, tentan construír o sentido desa realidade que semella difusa, por pouco clara e imprecisa.

Para Arboleda Arenas, «el caos hace referencia, no a desorden o falta de orden sino a aquellas situaciones fenomenológicas en las que se hace difícil y complejo predecir su evolución» (2016: 92). Nesa dirección, analizando os traballos escénicos de Robert Wilson, Wilcox sinala unha diferenza posible entre obras compactas, como Hedda Gleber de Henrik Ibsen, e obras en expansión, en tanto no tipo de estrutura dramática que propoñen, «all of the elements are subservient to the narrative and can be read in support of, or in opposition to, the movement of the plot» (Wilcox, 1996: 703), destacando que aí reside a diferenza entre «a system with a pre-inscribed linear trajectory and a chaotic system in which one is never certain what will happen next» (1996: 702). A obra dramática de Casares sería, xa que logo, unha obra en expansión, como se pode ver ao comparar o estado da horta na primeira escena e na última.

Como dixemos, a primeira escena de As laranxas..., na que se mostra o mundo dramático configurado, abre cun notable conflito cognitivo, quer para o lector, quer para Elías, que ao ver as laranxas corre en dirección á casa. E nesa dirección ese mundo recrea unha situación de «stasis», é dicir, de tensa incerteza, un estado de equilibrio imposible, e que ao estourar a primeira das laranxas xera un fenómeno de pura entropía, que provoca un desorde crecente que finalmente deriva nunha nova orde, moi diferente da primeira, e volvemos ás dúas visións da horta de Elías e Anxa. Segundo Vardoulakis, quen segue a etimoloxía academicamente aceptada, «stasis» deriva do verbo istamai ou istemi en grego antigo, polo que «can mean either to stand up, or to be standing, to be waiting. It can be either the movement upward or the state in which one finds oneself after the movement is completed» (2009: 127). Dun primeiro estado de «stasis» no inicio, pasamos a outro novo estado de equilibrio imposible na escena final, en tanto nin é conclusiva nin implosiva. Non se volve ao punto de partida, como acontece noutras pezas dramáticas que compactan a realidade.

Outro dos elementos fundamentais na hora de explicar As laranxas..., en tanto constitúe a ferramenta coa que os personaxes enfrontan o conflito cognitivo latente nesa primeira escena antes da aparición de Elías, é o que se coñece como pensamento diverxente, relacionado coa creatividade, que pola súa vez se ten considerado como un estilo cognitivo. Como sinala Alonso Monreal:

Los individuos creativos poseen el estilo cognitivo innovador: es un estilo específicamente concerniente a los creativos; les impulsa a buscar soluciones no frecuentes y diferentes, con el peligro de preferir lo nuevo a lo mejor. Poseen también el estilo de tolerancia a lo irreal, es decir, son capaces de aceptar experiencias que no parecen estar de acuerdo con lo verdadero (2000: 175). 
No seu traballo sobre o pensamento diverxente, a partir das achegas de Joy Paul Guilford ${ }^{13}$, Romo Santos sinala que a característica fundamental da persoa creadora «es la divergencia, la producción de diferentes alterativas de solución a los problemas, la libertad de pensamiento que no se constriñe al ofrecimiento de una solución única sino que presenta enfoques alternativos con soluciones diversas» (1987: 183). Considerando os aspectos básicos da «creatividad constructi$v a »$, Rogers falaba dunha apertura en relación á experiencia, entendida como «falta de rigidez, permeabilidad a los límites de los conceptos, creencias, percepciones e hipótesis, posibilidad de admitir la ambigüedad dondequiera que esta exista, capacidad de recibir información contradictoria sin sentirse impulsada a poner fin a la situación» (1986: 306). E así chegamos aos toromelos como metáfora de formas alternativas de ver e dicir o mundo, de explicalo, tamén ás actitudes de Anxa ou de Elías, de Toneladitas ou do Veciño da Escopeta.

\section{OS TOROMELOS COMO METÁFORA}

As autoras e autores que analizan os textos dramáticos na perspectiva das teorías consideradas neste traballo, parten de conceptos como non-linearidade, fragmentación, descontinuidade ou perspectivismo (Demastes, 1994; Reed, 1994; Flores, 2000). Tendo en conta esas catro nocións, na nosa aproximación ao texto de Casares imos non obstante utilizar criterios diferentes que abranguen cuestións que consideramos máis relevantes porque ademais de incluír as nocións sinaladas serven para mostrar onde radica a singularidade da peza. A exclamación do Veciño da Escopeta, «iVaia toromelos!» (Casares, 1993: 16), é unha boa mostra da actitude coa que os veciños e veciñas reaccionan ante unha realidade nova e que non admite explicación lóxica, e por iso cando descobren as laranxas «mostran asombro das máis diferentes maneiras. Con medo, con ledicia, aplaudindo... Cáseque todos reaccionan con ledicia» (Casares, 1993: 21). Con esa palabra, toromelos, mostran unha maneira de se posicionaren diante do inesperado, do incerto, do inexplicable, que non provoca a fuxida senón un desexo de interaccionar con esa nova realidade, cun espírito ledo, lúdico, ou coa prevención armada, no caso do Veciño da Escopeta.

No inicio de $O$ principiño, a obra de Antoine de Saint-Exupéry que Carlos Casares traduce para o galego en 1972, temos unha poderosa metáfora, similar á que nos propoñen os toromelos, que nos chega por mor do famoso debuxo dunha boa que papou un elefante enteiro e que para os adultos non representa máis que un simple sombreiro. A queixa do aviador diante desa lectura do seu debuxo é precisa: «As persoas maiores nunca comprenden nada por si soas e é fastidioso para os nenos terlles que andar dando sempre explicacións» (Saint-Exupéry,

13 Guilford (1897-1987) foi un psicólogo americano que estudou especialmente a estrutura da intelixencia humana, e autor de diversos traballos entre os que destaca o titulado «Creativity», publicado en 1950 pola revista American Psychologist. Entre os continuadores da súa investigación está Howard Gardner, quen formula a idea das intelixencias múltiples e un dos máximos defensores da educación artística como área curricular fundamental no desenvolvemento harmónico e integral da persoa (Vieites, 2015). 
2000: 11). Velaí temos xa unha interesante liña de traballo que nos leva a un eixe intertextual (Galanes, 2014; Luna Alonso, 2015) ${ }^{14}$, aínda que a anécdota tamén se poida vincular por outros vieiros cos presupostos da estética da recepción ${ }^{15}$.

No eixe intratextual, non podemos deixar de facer referencia ao libro de contos titulado A galiña azul, co que Carlos Casares gaña en 1968 na súa primeira edición o Concurso Nacional de Contos Infantís O Facho. Unha obra que Fernández Paz considera escrita a contracorrente pois naquela altura «no apartado da literatura infantil, pensábase que tampouco se podía eludir ese compromiso coa loita pola transformación dunha sociedade inxusta» (1989: 8), polo que se apreciaban especialmente os libros con mensaxe, en tanto se «miraba mal calquera cousa que non tivese, alomenos parcialmente, unha certa mensaxe explícita» (1989: 29), como acontecía en obras como Memorias dun negro labrego (1961) de Neira Vilas, ou Os soños na gaiola (1968) de Manuel María. Velaí un outro argumento para afirmar o carácter innovador do texto e esa súa dimensión non instrumental, que potencia a súa autonomía fronte ás tendencias dominantes naquela altura.

Lendo a primeira das historias contidas en A galiña azul, «O peixe da fonte do xardín», xa queda de manifesto que as cousas non son o que parecen e que a realidade semella ás veces estar gobernada por unha lóxica diferente, distinta, difusa, pois fronte á tendencia do poder de culpar sen probas (pensamento converxente, único), Leoncio mostrará que o peixe morre por querer salvar un paxaro, nun acto de xenerosidade extrema. E no volume temos, por suposto, esa galiña de cor azul, que non deixa de ser unha reivindicación do dereito á diferenza, a diverxencia, a un pensamento non asentado nin en antinomías nin en códigos binarios; as mesmas ideas que volven agromar con forza en As laranxas

Nesa primeira historia do peixe e do paxaro, Leoncio anuncia o invento dunha bomba que, a modo de piñata, contén todo tipo de cousas (Casares, 1983: 23), e que se fai realidade cando Anxa conta o conto para abrir as laranxas, e ao logralo todos reciben cadanseu agasallo, sexa o can Paulino (un óso enorme), Toneladitas (bocadillo), a veciña desdentada (bicicleta), Elías (pastilla de xabón), Veciña Sabida (corneta), Veciño Torto (lentes), Petra (pebi-

${ }_{14}$ Roig Rechou (2007) e Fernández Vázquez (2011) teñen destacado a influencia posible de mitos como a «cornucopia» o «corno da abundancia», presente en varias culturas, os relatos contidos en As mil e unha noites ou textos de Lewis Carroll, ben que no sistema literario galego teñamos figuras tan relevantes coma Dieste ou Cunqueiro para tomar como referentes previos.

15 En relación á Estética da Recepción, na súa xénese e desenvolvemento, son de especial interese as propostas de Vsevolod Meyerhod, que en 1906 formula a idea dun teatro da convención consciente que tería que incorporar un novo creador, o receptor (1971: 162). Anos despois nunha conferencia de 1930 , dirá que «El espectador que viene el teatro sabe que no se pretende una copia de la realidad, sino que él mismo debe, durante todo el tiempo del espectáculo, tratar de reconstruir el mundo con ayuda de su propia capacidad asociativa, partiendo del boceto que se le ofrece desde la escena. En vez de una casa completa verá un trozo de estufa o una ventana» (1971, p. 261). Unha visión da praxe teatral, en relación á súa recepción, que está en plena sintonía co construtivismo de Vigotsky, e na que aparecen ideas como a de «estrañamento», en tanto os obxectos tratados artisticamente adquiren unha nova dimensión que os volve estraños aos ollos do lector ou do espectador (Erlich, 1974: 252). 
da), ou o Veciño da Escopeta, a quen lle cae na testa a súa propia arma (a que saíra voando) cando quería roubar unha laranxa. Mais non estamos nun mundo de fantasía, senón nunha realidade en que dunha simple piñata de feira poden abrollar as cousas máis marabillosas, o que non deixa de ser unha defensa da festa popular como espazo comunitario para o encontro e o lecer da veciñanza, tal e como acontece ao final da historia na horta da Anxa.

\section{$O$ estrañamento da realidade}

Como se dixo, Casares parte dun estilo realista, recreando un mundo recoñecible nos seus elementos constitutivos, como esa «horta dunha casiña de planta baixa» onde «hai árbores, un pozo, un galiñeiro e a caseta dun can» (Casares, 1993: 8). Velaí o mundo que podería habitar calquera dos lectores do texto, ou recoñecer sen dificultade; non se trata porén dun mundo fantástico ou marabilloso, cheo de dragóns, elfos, princesas e gnomos. É, cando menos de primeiras, unha realidade cotiá, aínda que vaian aparecendo elementos estraños e vaian acontecendo sucesos igualmente estraños, co que pouco a pouco o mundo se volve do envés. Abonda conque nesa realidade cotiá irrompa un elemento estraño para que tal suceda. Así, nas primeiras liñas do texto secundario xa se mostra o carácter singular da realidade nese peculiar mundo dramático, no que habita un can chamado Paulino e a galiña Petra. Curiosamente nese mundo non atopamos nenos e nenas, senón persoas adultas, que deberán enfrontar un acontecemento singular, o feito de que aparezan da noite para o día cinco laranxas enormes.

A peza abre, en efecto, coa presentación e coa visión (a do lector/ espectador, e a dos habitantes do mundo que recrea) dunha natureza «estrañada», en tanto na horta hai unha árbore (que para Anxa é limoeiro, como o é para Elías) que deu froito estraños amais de enormes, hai animais con nomes rechamantes, e tamén vemos os zapatos enormes do tal Elías. Utilizamos a expresión «estrañada» en plena sintonía co sentido que lle deron formalistas rusos como Eikhenbaum ao considerar a «ostranenie» como un mecanismo para promover unha percepción diferente da realidade que toda obra artística crea, unha maneira igualmente de «destruir el automatismo perceptivo» ([1926], 2005: 61). Tal concepto, que Brecht retomará para falar de distanciamento ou «Verfremdungseffekt» (2004: 154), está asociado para Sklovski a unha noción da arte como descubrimento do mundo, e por iso consideraba que:

La finalidad del arte es dar una visión del objeto como visión y no como reconocimiento; los procedimientos del arte son el del extrañamiento de los objetos, y el que consiste en oscurecer la forma, en aumentar la dificultad y la duración de la percepción. El acto de percepción es en arte un fin en sí y debe ser prolongado ([1919] 2005: 73).

Nesa maneira de crear a realidade, e de tratar a materia dramática, nunha perspectiva «estrañada» e non convencional, partindo do realismo mais introducindo elementos non convencionais e máxicos, radica unha das claves da peza. Pois en efecto, para alén da hipérbole, tan querida aos máis cativos na súa 
visión e recreación do mundo, interesa especialmente o feito de que o azar se converta nun mecanismo artístico, capaz de provocar un alto grao de indeterminación e de facer que o curso de acción se torne aberto e mesmo aleatorio (Wilcox, 2008). Esa mesma indeterminación tamén aparece no texto secundario, na cualificación do «accidente» que padecen os viciños:

O zapato dereito do Veciño Gordo, Toneladitas por mal nome, vaise voando coma un paxaro. Ármase o lío correspondente. Cae un anaco do muro e o Veciño Gordo e demais acompañantes aparecen dentro da horta, tirados polo chan, víctimas dalgún indeterminado accidente (Casares, 1993: 23).

O dramaturgo implícito, autor do texto secundario co que comeza a obra, mestura elementos cotiás con elementos non cotiás, comezando polas enormes laranxas, e rematando pola caracterización de Elías, que amais de usar uns zapatos que «son os máis grandes do mundo, coma as laranxas» (Casares, 1993: 9), ou de que os zapatos non sexan irmáns, tamén mostra unha conduta asentada no estrañamento e na hipérbole, para estirarse, para lavarse ou para camiñar, e na que podemos ver unha pegada de accións dos personaxes interpretados por Charles Chaplin, Buster Keaton, e moi especialmente Oliver Hardy e Stan Laurel, particularmente no «gag» da folla superior de porta que se pecha, sen razón aparente, cando Elías quere entrar. Curiosamente, logo da primeira pancada, a que serve para marcar a convención cómica, Elías non se doe da cabeza senón do pé. Velaí un bo exemplo da diferenza entre a lóxica discreta (rascar onde se recibe a pancada ou como signo de estar cismando) e a lóxica difusa (rascar o pé), sendo esta última a que domina en toda a peza (Almache Cabrera, 2013).

\section{O azar e a complexidade}

Fernández Vázquez e Ferreira Boo, na súa consideración do texto que comentamos no marco da súa moi interesante análise crítica da literatura dramática infantil da época, sinalan a importancia da «anécdota azarosa» na configuración do mundo dramático da peza, o que supón en suma a irrupción do azar na vida cotiá das persoas (2015: 110), do mesmo xeito que a aparición do negro perpiaño de mármore entre a familia de primates nas primeiras secuencias de 2001: Una odisea espacial (1968), provoca non só a necesidade de darlle sentido senón tamén novos cursos de acción que en boa medida están marcados polo que se coñece como entropía. Termo este último que define un estado de desorde crecente que finalmente configura unha nova orde, pois como sinalaba Balandier: «El desorden se vuelve creador cuando se produce una pérdida de orden acompañada de una ganancia de orden, que es generador de un orden nuevo reemplazante del antiguo y que puede ser superior a él» (1999: 44). En relación ao concepto de entropía, resulta interesante a visión de Arnheim, quen sinala:

Entropy theory..., is not concerned with the probability of succession in a series of items but with the overall distribution of kinds of items in a given arrangement. The more remote the arrangement is from a random distribution, the lower will be its entropy and the higher its level of order (2001: 16). 
Considerando unha obra artística, diremos que nun cadro de Rubens como Las tres Gracias hai menos entropía que en calquera dos colaxes de Kurt Schwitters, polo que resulta especialmente relevante a disposición ou estrutura, que xamais deixa de mostrar unha determinada maneira de entender a vida, como suxire Arnheim (2001: 46), ou explicaba o psiquiatra Pablo Población:

(...) considero el acto creador como resultado de una desconfiguración de la realidad que a fuerza de habérsenos vuelto habitual, consuetudinaria, nos ciega, e impermeabiliza para otras formas de considerar el mundo en derredor, unida al proceso complementario de su reconstrucción o reorganización (1978: 21).

Esa idea da colaxe resulta especialmente axeitada para explicar unha peza na que as diferentes situacións se superpoñen, como veremos, como se fose unha composición cubista; varios planos superpostos dun cadro que no mundo dramático equivalen a unha situación na que os personaxes e os animais seguen cursos de acción independentes, sen que exista conexión causal entre tales cursos, como acontece na escena final. Na peza non hai unha acción única, principal e dominante, senón que van aparecendo cursos de acción en función desa estrutura azarosa, da que emerxe a complexidade, asentada nunha estrutura dispersa. Lembremos que pouco despois de que Anxa procure os «barreños e batedores» (Casares, 1993: 39) para bater un ovo co que se poderían facer «polo menos cen tortillas» (1993: 29), o ovo deixa de ser tal e «convértese nunha especie de fonte» (1993: 42). Azar e complexidade van da man, pois como sinalaba Morin «el desorden constituye la respuesta inevitable, necesaria e incluso, a menudo, fecunda, al carácter esclerotizado, esquemático, abstracto y simplificador del orden» (1994: 130). Fronte aos mundos grises, realismo máxico, e pensamento diverxente.

\section{A (des)configuración da trama nunha peza de estrutura aberta}

Fernández Paz, no seu comentario da peza, salienta que o texto «empeza cunha certa 'orde' e pouco a pouco vaise 'desmadrando', ata chegar ao rebumbio final» (1989: 29), tendo o tal «desmadre» e o tal «rebumbio» como causa primeira a aparición do que uns definirán como laranxas, outros como toromelos e outros como cirolas ${ }^{16}$, ou cereixas. E todo iso afecta a trama, ou estrutura da peza, que perde a linearidade e a causalidade inicial. A serie de acontecementos sería a seguinte: aparición das laranxas ou toromelos, zapatos enormes que non fan par, folla da porta que se pecha aleatoriamente, estoupido dunha laranxa, desmaio do Toneladitas, zapato voando, muro que se cae, Petra cun ovo enorme e vermello, a galiña ri, a laranxa fala, o ovo fala, a cara do Toneladitas ponse verde, o ovo continúa a falar, o ovo tórnase fonte, Petra enche a horta de ovos de todas as cores, o zapato aterra, o can ponse colorado, Toneladitas vólvese verde e despois desincha, a escopeta sae voando, Anxa conta contos, do

16 «Cirolas», no texto orixinal (Casares, 1993: 31). 
ceo cae un óso enorme, a laranxa abre e dela saen todo tipo de cousas, ármase unha boa xolda... Un conxunto de accións que se superpoñen, sen a lóxica da continuidade, máis ben coa da simultaneidade. Desa desorde extrema nace unha nova orde, o rebumbio final, na que todos semellan estaren satisfeitos, agás o Veciño da Escopeta, a quen lle cae a arma na testa por querer roubar unha laranxa.

Como podemos ver, desde o primeiro momento, os zapatos, enormes, e as laranxas, enormes, marcan a senda do inesperado. E a acción pouco a pouco vaise volvendo caótica, como ocorre nos xogos dramáticos de nenos e nenas, ou nesas dramatizacións nas que a liña argumental presenta os xiros máis inesperados e os personaxes aparecen e desaparecen ao chou, ou se transforman segundo a vontade do xogador, en tanto o espazo e o tempo, totalmente «desancorados», adquiren unha dimensión relativa, pois todo, absolutamente todo, é posible, como nos ensinaba Peter Slade nun estudio pioneiro editado en 1954, Child drama ${ }^{17}$. Prodúcese unha especie de «inversión del orden de las cosas» a partir da «efervescencia colectiva» producida pola chegada dos veciños ao escoitaren o ruído da escopeta, cos seus remuíños de ideas e pareceres e con todas as interaccións posteriores (Balandier, 1999: 118).

A peza recolle elementos da tradición oral, como o uso da hipérbole e o gusto polo inverosímil e a desmesura (Roig Rechou, 2007: 254), e na transición entre o discurso realista e os elementos fantásticos (Pena Presas, 2014; Fernández Vázquez + Ferreira Boo, 2015: 109), en todo momento opera con mecanismos propios da Fantástica, a disciplina que reivindicara Novalis e sobre a que Gianni Rodari escribiu a súa Grammatica della fantasia (1973). Velaí os contos de Anxa para abrir os ovos e abrir as fontes, para as galiñas chocas, ou o do ovo bo e o do ovo malo, ou o da laranxa boa e a laranxa mala; uns contos que cando non se din da maneira adecuada e coas palabras exactas provocan efectos inesperados, como a caída un óso do ceo, «óso de abondo para cen cans, de non existir o can Paulino» (Casares, 1993: 56).

Non estamos ante unha trama que siga na súa concreción unha causalidade lineal, pois a medida que se van sumando acontecementos azarosos, a súa complexidade aumenta, en tanto eses sucesos se van mesturando, de xeito que estean abertos varios cursos de acción ao mesmo tempo, de forma simultánea, o que afecta a conduta dos personaxes, e con esa posición diferenciada diante da realidade que cada un manifesta a peza cobra unha perspectiva múltiple. Velaí un exemplo desa simultaneidade:

De repente o ovo convértese nunha especie de fonte cichando para enriba. Elías o primeiro e logo tódolos demais afánanse en tapar o buraco, pero non poden. Póñense perdidos e vanse tornando amarelos, color ovo. En tanto, aparece polo fondo a galiña Petra. É unha galiña grande. Quizais non sexa a

17 No capítulo 11, titulado «Sugerencias para la escuela primaria», Slade recomendaba aos directores das escolas: «Cuando entren en un aula (o un vestíbulo) en los que haya más ruido que al que están acostumbrados, traten de comprender lo que está sucediendo. El clímax es tan consustancial a la buena expresión dramática como el estrépito a un taller» (1978: 187). 
galiña máis grande do mundo, pero é unha galiña que foi quen de poñer semellante ovo. Non só iso, senón que ademais vai encher a horta de ovos vermellos, azuis, verdes... Tamén leva lentes. E os lentes si que son, sen dúbida, os lentes máis grandes do mundo. Dende que entra ata que se vai, paséase, pon ovos e ri sen parar. Ninguén se decata da súa presenza porque están todos empeñados en cegar a fonte... (Casares, 1993: 42).

En certa medida nalgúns momentos a trama, en especial cando se presentan accións simultáneas, parece seguir a mesma pauta da escena do camarote na película dos Marx Brothers Unha noite na ópera (1935). Nesa dirección non segue o clásico esquema de presentación, desenvolvemento e desenlace, pois falta precisamente o desenlace, o que lemos ou miramos, por exemplo, en Un chapeu de palla italiana.

Desa simultaneidade abrolla outra das características singulares da peza, que se relaciona cos trazos que mellor definen os xogos e as dramatización dos máis cativos, pois sabemos como comezar pero o remate sempre é unha sorpresa, por esa renuncia a un desenvolvemento lineal e causal. A peza ten unha estrutura diferente das pezas tradicionais que teñen un final pechado, e presenta trazos do que se coñece como «obra aberta», que Pfister caracteriza como aquela na que «the structural openness consists in the fact that the story is no longer presented as a closed, hierarchically arranged whole, but as an ensemble of individual sequences that are relatively autonomous» (1991: 243), en función tamén da «refusal to supply an ending in which all the informational discrepancies are eliminated and all the conflicts resolved» (1991: 96). O que As laranxas... propoñen na escena final é un tránsito entre a realidade inicial e unha outra realidade na que os conflitos seguen sen resolverse, mais os personaxes aprenderon a vivir nesa nova orde na que algunhas laranxas seguen penduradas do limoeiro, os obxectos voan e falan, e o xardín está inzado de ovos de cores. Aumentou, xa que logo, a súa tolerancia á indeterminación, e por tanto a súa autonomía persoal.

Tamén paga a pena considerar como algúns conflitos se resolven mentres outros quedan abertos; así por exemplo, cando a peza semella rematar, queda unha laranxa aínda pendurada do limoeiro, pois unha «estoura como unha bomba» cando Elías a toca co dedo índice (1993: 12), outra cae ao chan e non estoupa (1993: 48), unha terceira cáelle ao Veciño da Escopeta na cachola (1993: 52), outra é a que Anxa consegue abrir e da que saen os agasallos todos (1993: 57), e unha quinta é a que o Veciño da Escopeta quere roubar (1993: 58) e que supoñemos aínda no limoeiro. Outro tanto acontece cos moitos ovos que a galiña Petra enche a horta, que se volve aínda máis multicolor. Elías vaise lavar no pozo coa pastilla de xabón máis no sabemos se desta vez vai poder librarse das tisnaduras, como tampouco podemos estar seguros de que Toneladitas vaia poder saciar tanta fame co seu bocadillo, e non queira de postre o que ten por cereixas... En realidade xérase unha nova situación na que todos teñen algo novo que facer, pero sen que signifique un estado de equilibrio pois o rebumbio do que falara con tanto acerto Fernández Paz continúa na última escena, na que cada quen anda coa súa nova teima mentres o Veciño da Escopeta leva un bo «palistrocazo» ao lle caer a súa escopeta na cachola (outro croque máis). E así 
cae o pano, mentres a Veciña Desdentada anda nunha bicicleta pequeniña, o Veciño torto cuns lentes enormes mira todas as cousas, a Veciña Sabida toca a corneta, Toneladitas come o bocadillo, Elías lava a cara cunha pastilla de xabón enorme, o can Paulino xoga co seu óso... Accións simultáneas que acontecen nun espazo cheo de ovos, laranxas caídas ao chan ou un muro medio derruído. Como antes se dixo, unha imaxe que pola súa riqueza de accións inconexas semella aqueloutra na que Groucho Marx enche de persoas e vida un pequeno camarote. Desorde e complexidade.

\section{Os personaxes}

Especial interese teñen os personaxes, que queren representar unha veciñanza común en calquera aldea galega, onde hai sempre elementos singulares, como un veciño gordo, que morre por comer, ou o veciño da escopeta, sempre disposto a impoñer a súa vontade mediante o uso da forza. Particular atención merecen Elías, apoucado e torpe, e Anxa, máis esperta e disposta a enfrontar situacións inesperadas, e que ademais é unha sorte de depositaria dos contos máis estraños, e da tradición oral; uns contos que cando se contan mal semellan castigar ao contador, como se tivesen vida, e por iso Anxa «ten o ollo dereito azourido» (Casares, 1993: 12), por non contar ben o conto das galiñas chocas (1993: 40). Tamén contan como personaxes, o can, a galiña, o ovo, ou as laranxas, todos eles dotados de fala, feito que engade complexidade á calquera escenificación.

Dos veciños todos, destacan Elías, Anxa, Toneladitas e o Veciño da Escopeta. Os dous primeiros pola súa actitude diante do estrañamento da súa realidade cotiá, ante a que responden de forma positiva, adaptándose aos cambios dun mundo en transformación. O Veciño Gordo, serve como punto de inflexión cómica, quer polos seus desmaios ante o tamaño das cousas que poden ser alimento, e a súa insistencia en comer tortilla, quer polos seus cambios de cor ou de peso ${ }^{18}$.

En relación ao Veciño da Escopeta, o que recibe máis croques, outro elemento cómico moi ben inserido e utilizado, vemos que representa o pensamento lineal, o desexo de orde, a autoridade, a violencia contra a que mesmo se revela a súa propia escopeta. A súa derrota definitiva, cando a escopeta que «marchara voando, voando volve» e lle cae na cabeza (1993: 58), tamén significa a derrota dunha maneira determinada de querer a realidade, aquela contra a

18 A obra presenta importantes dificultades en relación á súa escenificación, por moito que as ilustracións magníficas de Luís Seoane teñan especial interese na consideración do espazo escénico e no deseño dos personaxes. Os problemas son diversos, desde os obxectos voadores á textura e forma das cousas e dos animais, sexa o can ou a galiña. Tamén niso Casares soubo apostar pola necesidade da renovación teatral, en especial neste caso para recrear esa natureza estrañada, azarosa, indeterminada, caótica, algo que en ningún caso se logrou nos espectáculos máis recentes, tal vez por partir dunha lectura demasiado lúdica do texto que esquecía toda a fondura filosófica que agocha. Por iso mesmo o espectáculo resultante podería estar dirixido sen problemas ao público adulto, pois en ningún caso se incorre no «infantilismo» tan abundante naquel altura. 
que se revelan os veciños todos ao aceptar e dar sentido a ese novo mundo que habitan e cheo de tantas sorpresas.

\section{CONCLUSIÓNS}

Na súa breve pero interesante lectura das primeiras obras para a infancia publicadas en galego en Galicia, Fernández Paz sinala que «a historia da galiña azul acaba sendo un contundente alegato contra a uniformidade e un eloxio da diferenza e da liberdade» (1989: 8), e continúa a dicir que «Casares escolleu o compromiso máis fondo, o compromiso coa lingua, e proporcionoulle á literatura infantil galega un punto de referencia» (1989: 9). Pero Casares, ao facelo así, tamén escollía un compromiso coa autonomía da literatura, por partida dobre.

Por unha banda renunciando a utilizar os relatos, metáforas e símbolos da identidade nacional como elementos para mostrar o estado de submisión e sometemento, para elaborar pola súa vez un discurso contra un pensamento único que se tiña instalado con forza en numerosos discursos, mesmo naqueles que falaban de liberación e que sen embargo impoñían unha visión dicotómica e binaria da realidade, asentada en duras antinomías que renunciaban á escala de grises. Pola outra fuxindo dalgunhas tendencias dominantes na escrita para os máis cativos e das que falaba Miguel Ángel Almodóvar nun traballo sobre as temáticas da literatura infantil e xuvenil, no que presentaba catro tipoloxías básicas partindo dun corpus textual conformado nos anos sesenta, setenta e primeiros oitenta; serían: (i) exaltación do infantil fronte ao adulto, (ii) vindicación - ecoloxismo, (iii) desmitificación do conto tradicional, e (iv) a non temática ou os disfraces do ludismo (1987: 87). A peza de Casares non cadra en ningunha desas categorías, quizais porque estea máis vinculada con outras tendencias emerxentes como podería ser a dos contos asentados nun realismo máxico alleo a princesas e fadas, e asentado nunha realidade que ás veces mostra facianas inesperadas, porque esa é a maneira en que os nenos e nenas se relacionan coa realidade ou crean as súas propias historias.

Ao falar da «fin das certezas», Prigogine (1997) describe un proceso por medio do que podemos recuperar a posibilidade do misterio, do asombro, da sorpresa, fundamental nos dominios da arte, e con Morin deberiamos considerar que:

El pensamiento complejo no es el pensamiento completo; por el contrario, sabe de antemano que siempre hay incertidumbre. Por eso mismo escapa al dogmatismo arrogante que reina en los pensamientos no complejos. Pero el pensamiento complejo no cae en un escepticismo resignado porque, operando una ruptura total con el dogmatismo de la certeza, se lanza valerosamente a la aventura incierta del pensamiento, se une así a la aventura incierta de la humanidad desde su nacimiento (1998: 440).

Como se dixo, o texto de Casares abrolla nun contexto histórico no que as circunstancias socioculturais e políticas esixían que toda manifestación artística 
tivese unha dimensión instrumental e que levase, de forma explícita, as marcas dunha denuncia contra a ditadura, de forma directa ou a través de diversas alegorías, pero tamén símbolos e metáforas cunha forte dimensión identitaria. Casares pola contra aposta polo uso da lingua e por un modelo de composición dramática que, co seu carácter aberto e complexo, esixe do lector novas estratexias para dar sentido ao mundo recreado, mesmo para seguir as diferentes peripecias que nel van agromando. Andamos tamén polos territorios da estética da recepción, daquilo que Sanchis Sinisterra definiu como dramaturxia da recepción, pois en efecto:

Un espectáculo, una obra, no es una emisión unilateral de signos, no es una
donación de significados que se produce desde la escena a la sala -o desde el
texto hacia el lector-, sino un proceso interactivo, un sistema basado en el
principio de la retroalimentación, en el que el texto propone unas estructuras
indeterminadas de significado y el lector rellena esas estructuras indetermina-
das, esos huecos, con su propia enciclopedia vital, con su experiencia, con su
cultura, con sus expectativas. Y de ahí se produce un movimiento que es el
que genera la obra de arte o la experiencia estética (1995: 67).

Lembramos que en Psicología del arte (1925), Vigotsky sinalaba en relación á percepción artística que «no sólo interpretamos las obras de arte de forma distinta, sino que las experimentamos y sentimos de manera distinta» (2006, p. 66), en tanto «la cuestión no es el contenido planeado por el autor sino el que le atribuye el lector» pois entendía que «el contenido de una obra de arte es una cantidad dependiente y variable, una función de la psique del hombre social» (2006, p. 64).

Casares, xa que logo, aposta por un lector intelixente, capaz de darlle sentido ao rebumbio, á desmesura, á hipérbole, capaz de construír significados polos vieiros dunha imaxinación entroncada coa transformación do real, coma en calquera das prácticas socioculturais e artísticas nas que os nenos xogan a facer teatro, pois como dicía Peter Brook, «una obra de teatro es juego» (1973: 200). E por iso As laranxas..., seguen a ser unha invitación a xogar.

\section{BIBLIOGRAFÍA}

Almache Cabrera, J. (2013) «Lógica discreta y lógica difusa: Facetas que las caracterizan», Estoa, 2, pp. 91-101.

Almodóvar, M. Á. (1987) «El autor y las temáticas en el teatro para niños», en VV. AA., Teatro de, por, para... los niños, Madrid, Acción Educativa, pp. 85-93.

Alonso, F. (2003) «A obra infantil de Carlos Casares». Revista de Estudos Miñoranos. Dispoñible en: http://www.aelg.org/centro-documentacion/ autores-as/fran-alonso/paratextos/1313/a-obra-infantil-de-carlos-casares

Alonso Monreal, C. (2000) Qué es la creatividad, Madrid, Biblioteca Nueva. 
Arboleda Arenas, A. (2016) «La Escuela bajo los preceptos de la Teoría del Caos: incertidumbre, caos, complejidad, lógica difusa y bioaprendizajes», Biociencias, 11 (1), pp. 91-103.

Arnheim, R. (2001) Entropy and Art. An Essay on disorder and order. Dispoñible en: http://www.aakkozzll.com/pdf/arnheim.pdf

Aróstegui, J. (1995) La investigación histórica: teoría y método, Barcelona, Crítica.

Balandier, G. (1999) El desorden. Las teorías del caos y las ciencias sociales, Barcelona, Gedisa.

Bardoulakis, D. (2009) «Stasis: Beyond Political Theology?», Cultural Critique, 73, pp. 125-147.

Basanta, Á. (2012) «A traxectoria narrativa de Carlos Casares», Grial, 196, pp. 17-27.

Blanco Amor, E. (1974) Teatro pra a xente, Vigo, Galaxia.

Bourdieu, P. (1995) Las reglas del arte, Barcelona, Anagrama.

Brady, P. (1990) «Chaos Theory, Control Theory, and Literary Theory or: A Story of Three Butterflies», Modern Language Studies, 20 (4), pp. 65-79.

Brecht, B. (2004) Escritos sobre teatro, Barcelona, Alba.

Brook, P. (1973) El espacio vacío, Barcelona, Península.

Bunge, M. (2002) Crisis y reconstrucción de la filosofía, Barcelona, Gedisa.

Calvo, J. L. (2012) Barriga Verde, Manuel María e o San Froilán, Lugo, Concello de Lugo.

Campoy, C. (2015) O teatro popular de marionetas como medio de comunicación das subalternas. O caso do espectáculo de Barriga Verde na Galiza da postguerra (1939-1960). Tese de doutoramento, Universidade de Santiago. Dispoñible en: https://minerva.usc.es/xmlui/handle/10347/14577

Casares, C. (1983) A galiña azul, Vigo, Galaxia.

- (1993) As laranxas máis laranxas de tódalas laranxas, Vigo, Galaxia.

Cervera, J. (1982) Historia crítica del teatro infantil español, Madrid, Editora Nacional.

De Marinis, M. (1988) El nuevo teatro, 1947-1970, Barcelona, Paidós.

Demastes, W. W. (1994) «Re-Inspecting the Crack in the Chimney: Chaos Theory from Ibsen to Stoppard», New Theatre Quarterly, 10, pp. 242-254.

Eikhenbaum, B. (2005) «La teoría del 'método formal'», en J. M. Cuesta Abad + J. Jiménez Heffernan (eds.), Teorías literarias del siglo XX, Madrid, Akal, pp. 50-66.

Erlich, V. (1974) El formalismo ruso, Barcelona, Seix Barral. 
Fernández Paz, A. (1989) 28 libros de literatura infantil e xuvenil galega, Santiago de Compostela, Consellería de Cultura e Deportes, Andel, 5.

Fernández Vázquez, M. (2011) «Los premios literarios, una estrategia en Carlos Casares», ANILIJ, Anuario de Investigación en Literatura Infantil y Juvenil, 9, pp. 61-69.

- (2012) «Carlos Casares en la configuración del campo literario infantil y juvenil en lengua gallega», en R. Ramos + A. Fernández Mosquera (eds.), Literatura Infantil y Juvenil y diversidad cultural, Vigo/Braga, ANILIJ, Universidade do Minho, pp. 167-187.

Fernández Vázquez, M. + Ferreira Boo, C. (2015) «Literatura dramática», en B.-A. Roig Rechou (ed.), Historia da Literatura Infantil e Xuvenil Galega, Vigo, Xerais, pp. 105-112.

Flores, R. (1994) «A Portrait of Don Quixote from the Palette of Chaos Theory», Cervantes, 22 (1), pp. 43-70

Galanes, I. (2014) «Carlos Casares y la traducción: obra dispersa e inédita», Quaderns. Revista de Traducció, 21, pp. 183-198.

García Negro, M. P. (2009) «O teatro de Manuel María», en Actas do Congreso Manuel María: literatura e nación, A Coruña, Universidade de A Coruña, pp. 227-250.

García Valero, B. E. (2012) «Realismo mágico, física cuántica y Japón», Inter Asia Papers, 26, pp. 1-30.

Gleick, J. (1988) Caos: la creación de una ciencia, Barcelona, Seix Barral.

González Millán X. (1994) «Do nacionalismo literario a unha literatura nacional. Hipóteses de traballo para un estudio institucional da literatura galega», Anuario de Estudios Literarios Galegos, 1994, pp. 66-81.

- (1998) «A reconfiguración do espazo literario galego actual: transformacións e desafíos», en M. F. Vieites (ed.), Do novo teatro á nova dramaturxia (1965-1995), Vigo, Xerais, pp. 15-32.

Guede Oliva, M. (2002) «Débolle visita a Ribadavia», en I. López Silva + D. Vilavedra, Un abrente teatral, Vigo, Galaxia, pp. 242-245.

Gurriarán, R. (coord.) (2012) Un canto e unha luz na noite. Asociacionismo cultural en Galicia (1961-1975), Compostela, Consello da Cultura Galega.

Habermas, J. (1982) Conocimiento e interés, Madrid, Taurus.

Hayles, K. N. (1990) Chaos Bound. Orderly Disorder in Contemporary Literature and Science, Ithaca, NY, Cornell University Press.

Hippolyte, J. L. (2006) Fuzzy Fiction, Lincoln, NE, University of Nebraska Press.

Hjelmslev, Louis (1972) Ensayos lingüísticos, Madrid, Gredos. 
Hoppmann, M. J. (2014) «A Modern Theory of Stasis», Philosophy and Rhetoric, 47 (3), pp. 273-296.

Horkheimer, M. (2000) Teoría tradicional y teoría crítica, Barcelona, Paidós.

Innes, Ch. (1992) Avant Garde Theatre, 1892-1992, London, Routledge.

Kellert, S. H. (2008) Borrowed Knowledge: Chaos Theory and the Challenge of Learning across Disciplines, Chicago, Chicago University Press.

Kosko, B. (1995) Pensamiento borroso: la nueva ciencia de la lógica borrosa, Barcelona, Crítica.

Kundert-Gibbs, J. L. (1999) No-Thing Is Left to Tell: Zen/Chaos Theory in the Dramatic Art of Samuel Beckett, Madison, NJ, Fairleigh Dickinson University Press.

López Guil, I. (2005) «Álvaro Cunqueiro y sus Flores del año mil y pico de ave», Dicenda, Cuadernos de Filología Hispánica, 23, pp. 151-163.

López Silva, I. + Vilavedra, D. (2002) Un Abrente teatral, Vigo, Galaxia.

Lorenzo, M. (1970) «Castelao, ausente», Primer Acto, 120, pp. 26-27.

- (2012) «Desembarco», en R. Gurriarán (coord.), Un canto e unha luz na noite. Asociacionismo cultural en Galicia (1961-1975), Compostela, Consello da Cultura Galega, pp. 35-37.

Lourenzo, M. + Pillado Mayor, F. (1979) O teatro galego, Sada, Ediciós do Castro.

- (1987) Dicionário do teatro galego (1671-1985), Compostela, Sotelo Blanco.

Lourenzo Modia, C. (2012) O teatro circo na configuración do teatro independente galego (1967-1978), Tese de doutorado, Universidade de A Coruña. Dispoñible en: http://illa.udc.es/Repository/Thesis/1418638256943_LourenzoModia_Cilla_TD_2012.pdf

Luna Alonso, A. (2015) «El manuscrito inédito de O principiño. Un texto fundacional de la literatura gallega traducida», Çédille, revista de estudios franceses, 11, pp. 363-388.

María, M. (1970) «Noticia del teatro gallego», Primer Acto, 120, pp. 8-17.

Matheson, C. + Kirchhoff, E. (1997) «Chaos and Literature», Philosophy and Literature, 21(1), pp. 28-45.

McCarthy, J. A. (2006) Remapping Reality: Chaos and Creativity in Science and Literature (Goethe, Nietzsche, Grass), Amsterdam, Rodopi.

Meyerhod, V. (1971) Textos teóricos I, Madrid, Alberto Corazón.

Morin, E. (1994) Introducción al pensamiento complejo, Barcelona, Gedisa.

- (1998) «Epistemología de la complejidad», en D. Fried Schnitman (ed.), Nuevos paradigmas, Cultura y Subjetividad, Barcelona, Paidós, pp. 421-442. 
- (2016) Enseñar a vivir. Manifiesto para cambiar la educación, Barcelona, Paidós.

Ogando González, I. (2007) «A formación e a investigación teatral en Galicia», en M. F. Vieites (ed.), 125 anos de teatro en galego. Galicia 1882-2007, Vigo, Galaxia + Xunta de Galicia, pp. 319-334.

Pena Presas, M. (2014) «A relación de Carlos Casares co mundo da infancia: os anos do pensador da cultura, 1968-1985», Grial, 201, pp. 80-89.

Pfister, M. (1991) The Theory and Analysis of Drama, Cambridge, Cambridge University Press.

Piñeiro, D. (2002) «Abrente e o teatro aleccionado», en I. López Silva + D. Vilavedra, Un abrente teatral, Vigo, Galaxia, pp. 269-273.

Piñeiro Pais, L. (2015) «Identidade e alteridade en Vento ferido de Carlos Casares», Madrygal, 18, pp. 127-137.

Población, P. (1978) «Prólogo», en E. Gili, y P. O’Donnell, El Juego. Técnicas Lúdicas en Psicoterapia de Adultos, Barcelona, Gedisa.

Prigogine, I. (1997) El fin de las certidumbres, Madrid, Taurus.

Reed, C. A. (1994) «Chaotic Quijote: Complexity, Nonlinearity, and Perspectivism», Hispania, 77 (4), pp. 738-749.

- (1996) «No está olvidada la ciencia: Science, Chaos Theory, and Tragedy in El médico de su honra», South Central Review, 13 (1), pp. 26-39.

Riobó, P. P. (1999) O teatro galego contemporáneo (1936-1996), A Coruña, Universidade de A Coruña.

Rodari, G. (1982) Gramática de la fantasía, Barcelona, Avance.

Rogers, C. (1986) El proceso de convertirse en persona, Barcelona, Paidós.

Roig Rechou, B. A. (2002) «Literatura infantil e xuvenil. Carlos Casares in memoriam (1942-2002)», Revista Galega do Ensino, 35, pp. 235-243.

- (2004) «O contexto», en C. Casares, As laranxas máis laranxas de todas as laranxas, Santiago de Compostela, IGAEM, pp. 41-105.

- (2007) «Teatro do absurdo, humor e realismo crítico en As laranxas máis laranxas de todas as laranxas», en B.-A. Roig Rechou + P. Lucas Domínguez + I. Soto López (coords.), Teatro infantil. Do texto á representación, Vigo, Xerais, pp. 241-250.

— (coord.) (2015) Historia da Literatura Infantil e Xuvenil Galega, Vigo, Xerais.

Roig Rechou, B. A. + López, M. P. (2007) «Panorama histórico do teatro infantil galego», en B.-A. Roig Rechou + P. Lucas Domínguez + I. Soto López (coords.), Teatro infantil. Do texto á representación, Vigo, Xerais, pp. 99-120. 
Romo Santos, M. (1987) «Treinta y cinco años de pensamiento divergente: teoría de la creatividad de Guilford», Estudios de Psicología, 27-28, pp. 175-192.

Ruibal, E. R. (1974) «¿Unha nova xeira do noso teatro?», El Ideal Gallego, 05/05/1974.

Sanchis Sinisterra, J. (1995) «Por una dramaturgia de la recepción», ADE/Teatro, 41-42, pp. 64-69.

Saint-Exupéry, A. (2000) O principiño, tradución de C. Casares, Vigo, Galaxia.

Shklovski, V. (2005) «El arte como artificio», en J. M. Cuesta Abad + J. Jiménez Heffernan (eds.), Teorías literarias del siglo XX, Madrid, Akal, pp. 67-73.

Slade, P. (1978) Expresión dramática infantil, Madrid, Santillana.

Sokal, A. + Bricmont, J. (1999) Imposturas intelectuales, Barcelona, Paidós.

Valenzuela, L. (2002) «Julio Cortázar más allá de la vigilia», en L. Valenzuela + B. Jozef + A. Sincard (eds.), Julio Cortázar desde tres perspectivas, México, Fondo de Cultura Económica, pp. 13-30.

Velarde Lombraña, J. (1996) «Pensamiento difuso, pero no confuso: de Aristóteles a Zadeh (y vuelta)», Psicothema, 1996, 8 (2), pp. 435-446.

Vieites, M. F. (1996) «Una nueva dramaturgia para un nuevo teatro. Ribadavia, 1973-1989», Primer acto, 262, pp. 9-17.

- (1998) La nueva dramaturgia gallega. Estudio y antología, Madrid, Publicaciones de la ADE.

- (2001) «Territorios do(s) teatro(s) e teatro(s) para os territorios: algunhas reflexións arredor das políticas culturais, as políticas teatrais, o tecido teatral e as compañías residentes», en M. F. Vieites (coord.), Galicia e a residencia teatral: compañías residentes e regularización do tecido teatral, Compostela, Consello da Cultura Galega, pp. 13-115.

- (2003) «As representacións da nación no teatro galego (A propósito de Alén, un texto inaugural de Xaime Quintanilla)», Madrygal, 6, pp. 125-144.

- (2004) «Creación escénica, toromelos e teorías do caos: a propósito dun texto dramático de Carlos Casares», Revista Galega de Teatro, 37, pp. 34-42.

- (2005) «As laranxas máis laranxas de todalas laranxas y las teorías del caos», en V. Ruzicka Kenfel + C. Vázquez García + L. Lorenzo García (eds.), Mundos en conflicto: representación de ideologías, enfrentamientos sociales y guerras en la literatura infantil y juvenil: III Congreso Internacional de ANILIJ, Vigo, Universidade de Vigo, pp. 453-465.

- (2008) «El personaje dramático. Aspectos generales», en J. A. Hormigón (ed.), Del personaje literario-dramático al personaje escénico, Madrid, Publicaciones de la ADE, pp. 41-200. 
- (2009) «Profesión, profesionalidade, profesionalización, profesionalismo», Revista Galega de Teatro, 60, pp. 7-20.

- (2014) «Toromelos, laranxas e tortilla», Faro da cultura, 515, 16/10, p. 8.

- (2015) «De la naturaleza educativa de la educación teatral y de sus rasgos pertinentes», REIPE, Revista de Estudios e Investigación en Psicología y Educación, volumen extra (04), pp. 21-25. Dispoñible en: http://revistas. udc.es/index.php/reipe/issue/view/50/showToc

- (2016) «La obra dramática de Valle-Inclán y la nueva objetividad. Una hipótesis», Cuadrante, 33, pp. 32-75.

Vigotsky, L. (2008) Psicología del arte, Barcelona, Paidós.

Wilcox, D. (2008) «How Do You Read a Sign that No One Has Ever Seen Before?: A Post-Semiotic Analysis of Chance-Driven Events», Journal of Dramatic Theory and Criticism, 22 (2), pp. 103-117. 
